\title{
SRI 67th Annual Meeting Announcement
}

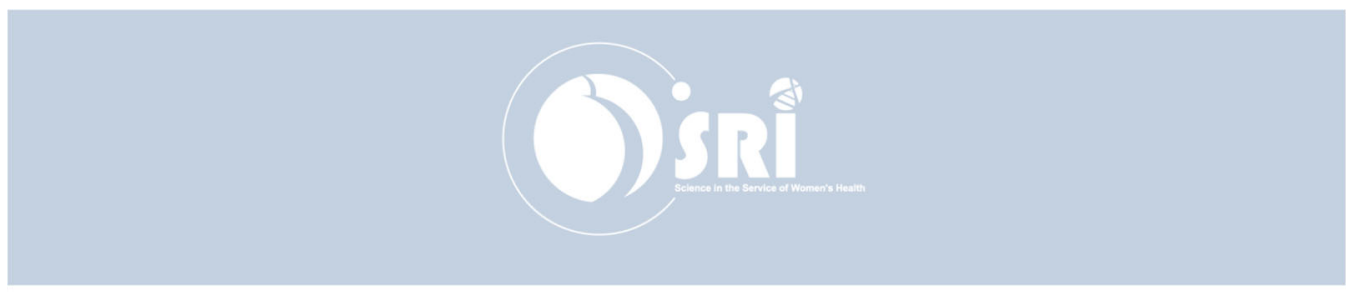

Society for Reproductive Investigation - 67th Annual Scientific Meeting

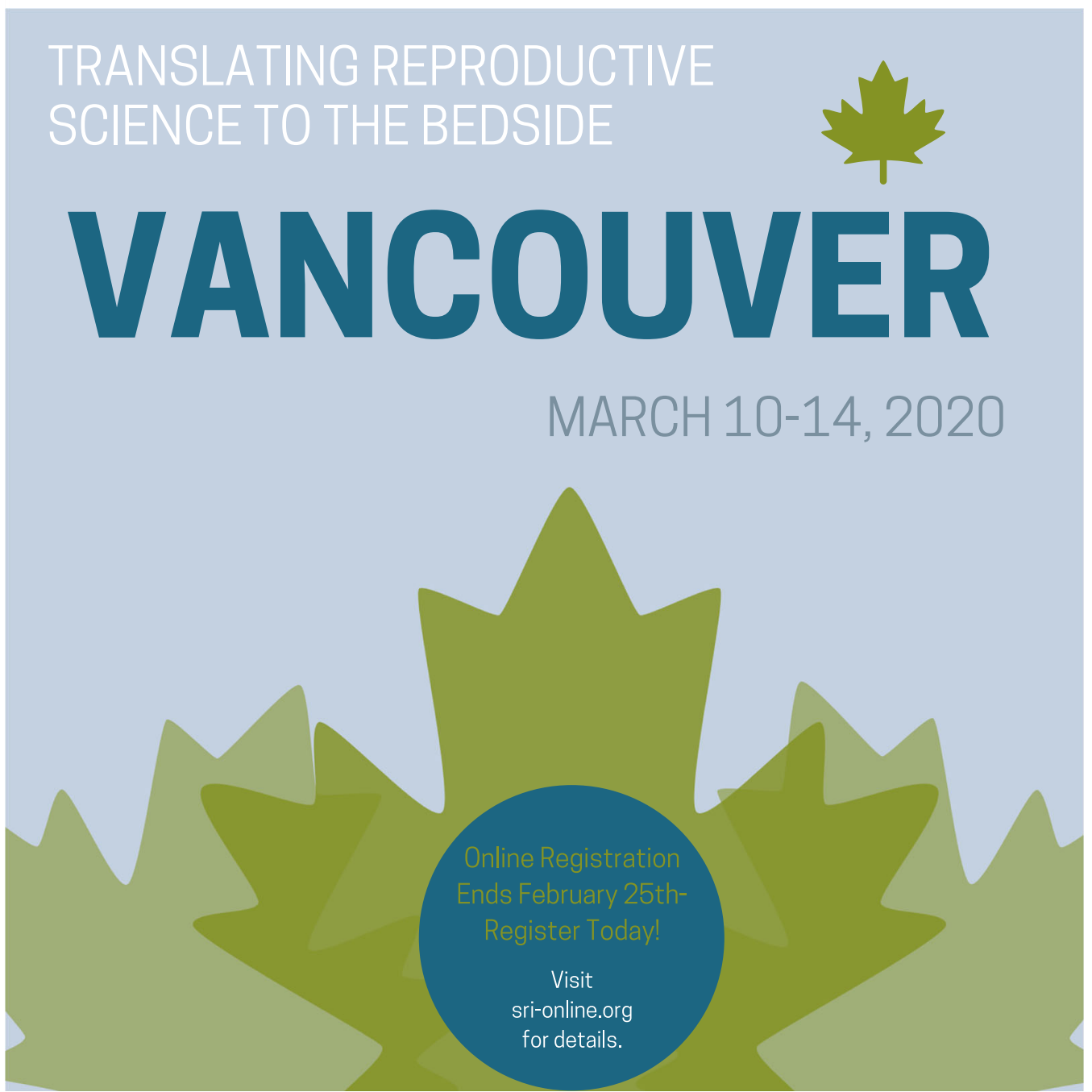

